\title{
A Highly Selective and Fast-Responding Hydrogen Sensor based on $\operatorname{In}_{2} \mathrm{O}_{3}$ Nanocubes
}

\author{
S. S. Tongaonkar ${ }^{1}$, Pradip Patil ${ }^{2}$ \\ ${ }^{1}$ Department of Physics, Moolji Jaitha College, Jalgaon 425 001, Maharashtra, India \\ ${ }^{2}$ Department of Physics, North Maharashtra University, Jalgaon 425 001, Maharashtra, India
}

\begin{abstract}
The $\mathrm{In}_{2} \mathrm{O}_{3}$ nanocubeswere successfully synthesized without any templates by calcining the $\mathrm{In}(\mathrm{OH})_{3}$ precursor in air at $300^{\circ} \mathrm{C}$ for $2 \mathrm{~h}$ and their $\mathrm{H}_{2}$ sensing characteristics were investigated. The $\mathrm{In}(\mathrm{OH})_{3}$ precursor was prepared through a wet chemical route at room temperature $\left(27^{\circ} \mathrm{C}\right)$ using $\mathrm{InCl}_{3}, 4 \mathrm{H}_{2} \mathrm{O}$ and $\mathrm{NH}_{4} \mathrm{OHas}$ starting materials.The formation ofI $\mathrm{n}_{2} \mathrm{O}_{3}$ nanocubes was confirmed by $\mathrm{X}$-ray diffraction measurement (XRD), X-ray photoelectron spectroscopy (XPS)and transmission electron microscopy (TEM)analysis.The In ${ }_{2} \mathrm{O}_{3}$ nanocubes exhibit excellent $\mathrm{H}_{2}$ sensing properties such as, high gas response $\left(\sim 130\right.$ to 50 ppm $\mathrm{H}_{2}$ at $\left.325^{\circ} \mathrm{C}\right)$, extremely rapid response (1s), fast recovery (4-5 s), excellent repeatability and good selectivity. Furthermore, the lower detection limit is $\sim 3.87$ ppm, which is lower than the permissible explosive limit for $\mathrm{H}_{2}$. The experimental results demonstrate the potential of theIn $\mathrm{O}_{3}$ nanocubes as sensing material in the fabrication of hydrogen sensors.
\end{abstract}

Keywords: $\operatorname{In}_{2} \mathrm{O}_{3}$ nanocubes, $\mathrm{H}_{2}$ sensor, Semiconductor gas sensors, TEM, XRD.

\section{Introduction}

Hydrogen $\left(\mathrm{H}_{2}\right)$ gas, due to its efficient fuel properties like high burning velocity, large heat of combustion $(142 \mathrm{~kJ} / \mathrm{g})$, low minimum ignition energy $(0.017 \mathrm{~mJ})$ and wide flammable range (4-75\%), offers its candidature for future generation energy source[1]. The burning product of hydrogen is water which is clean and can again be converted into hydrogen and oxygen. This property further makes it a clean and renewable energy fuel source for cars, buses, and other vehicles [2].Liquid hydrogen is used as a fuel for rockets. Monitoring/controlling of the hydrogen concentration is also is crucial in nuclear reactors, coal mines and semiconductor manufacturing. [3-5] . However, hydrogen gas is tasteless, colourless, odourless and leaks with large diffusion coefficient $\left(0.61 \mathrm{~cm}^{2} / \mathrm{s}\right)$. It catches fire even at low volume concentrations $(>4 \mathrm{ppm})$ and has large flame propagation velocity [6-8].Therefore, uses of hydrogen in technological applications are generally associated with effective execution of sensors to detect or critically monitor minute hydrogen leakages.

Semiconductor metal oxides are historically and generally investigated as hydrogen sensors. V. Aroutiounian [9] has reviewed, complied and tabulated some important data (from 1966 to 2006) about hydrogen sensing properties metal oxides along with effect of doping by metal nano particles and another metal oxide. Recently, Haoshuang et.al [1] have provided a comprehensive review on the hydrogen gas sensors based on metal oxide thin films and one-dimensional (1D) nanostructures for the period 2007-2012 in which the hydrogen sensing mechanism and some critical issues are discussed. The influences of grain size, porosity, orientation, doping and surface decoration as well as the device architecture on the sensing performance of hydrogen sensors is also widely investigated for improving gas selectivity and hydrogen response at low temperatures.

Recently, Wadkar et.al [10] al have reported a high performance $\mathrm{H}_{2}$ sensor based on $\mathrm{ZnSnO}_{3}$ cubic crystallites synthesized by a hydrothermal method. Amongst other recent studies, Katoch et. al [11] have reported $\mathrm{SnO}_{2}-\mathrm{ZnO}$ nano fiber composite for drastically enhancing the sensing behavior $\mathrm{H}_{2}$ gas and Wang et.al [12] report a low temperature, high performance hydrogen gas sensors using palladium decorated tungsten oxide.

Indium oxide $\left(\mathrm{In}_{2} \mathrm{O}_{3}\right)$ is an important wide band gap (3.55$3.75 \mathrm{eV})$, transparent material with attractive optoelectronic properties suitable for applications in solar cells[13].Ithas received considerable attention because of its high electron affinity and low electron effective mass and increasingly extensive applications in fuel cells [14-15 ], sensors [16], nano scale transistors [17] and flat-panel display materials [18]. $\mathrm{In}_{2} \mathrm{O}_{3}$, as an n-type semiconductor, has proven to be a highly sensitive material for the detection of both reducing and oxidizing gases [19].Few research groups have recently studied $\mathrm{H}_{2}$ sensors based on pure $\operatorname{In}_{2} \mathrm{O}_{3}$ nanostructures with different morphologies [21, 22]. Qurashi et. al [20] reported the $\mathrm{H}_{2}$ sensor based on $\mathrm{In}_{2} \mathrm{O}_{3}$ nano wires $(\sim 70 \mathrm{~nm})$ and nano needles (150-200 nm) synthesized via catalyst supported growth by vapor transport. The $\operatorname{In}_{2} \mathrm{O}_{3}$ nanowires showed a maximum response of about 0.6 at $400{ }^{\circ} \mathrm{C}$ with the response and recovery times of $\sim 31 \mathrm{~s}$ and $\sim 80 \mathrm{~s}$ for $500 \mathrm{ppm}$ of $\mathrm{H}_{2}$ at $200{ }^{\circ} \mathrm{C}$, respectively. The nano needles exhibited a maximum response of 0.25 at $350{ }^{\circ} \mathrm{C}$ with response time of $60 \mathrm{~s}$. More recently, Zheng et. al [21] reported hydrogen sensing properties of $\mathrm{In}_{2} \mathrm{O}_{3}$ nano towers with an octahedral cap size of $600 \mathrm{~nm}$ synthesized via thermal evaporation of $\operatorname{In}_{2} \mathrm{O}_{3}$ and active carbon powders. The $\operatorname{In}_{2} \mathrm{O}_{3}$ nano towers showed a high response of $83 \%$ towards $1000 \mathrm{ppm}$ of $\mathrm{H}_{2}$ at $240{ }^{\circ} \mathrm{C}$ with a response time of $63 \mathrm{~s}$. The detailed study on the influence of morphology of $\operatorname{In}_{2} \mathrm{O}_{3}$ on the $\mathrm{H}_{2}$ gas sensing properties was reported recently by Shanmugasundaram et. al [22]. These authors prepared the $\mathrm{In}_{2} \mathrm{O}_{3}$ having different morphologies like nanobricks $(200 \mathrm{~nm} \times 200 \mathrm{~nm} \times 50 \mathrm{~nm})$ nano particles $(10-$ $20 \mathrm{~nm})$, mesoporous nannocubes $(200 \mathrm{~nm} \times 200 \mathrm{~nm} \times 200$ $\mathrm{nm})$ and nanoflakes by using a facile hydrothermal route. This study unambiguously demonstrated thatthe sensing performance of nanocubes is far more superior than the other 


\section{International Journal of Science and Research (IJSR) \\ ISSN (Online): 2319-7064}

Index Copernicus Value (2013): 6.14 | Impact Factor (2014): 5.611

morphologies. The $\mathrm{In}_{2} \mathrm{O}_{3}$ nanocubes sensor exhibited response of 980 with the response and recovery times of $\sim 39$ $\mathrm{s}$ and $\sim 115 \mathrm{~s}$ for $0.5 \mathrm{ppm}$ of $\mathrm{H}_{2}$ at $150{ }^{\circ} \mathrm{C}$, respectively.

Within the present investigation, experiments have been carried out for the fabrication of a highly selective and fast responding $\mathrm{H}_{2}$ sensor based on $\mathrm{In}_{2} \mathrm{O}_{3}$ cubic crystallites. In this study, the $\mathrm{In}_{2} \mathrm{O}_{3}$ cubic crystallites were synthesized through a wet chemical route at room temperature. Sensing characteristics of the $\mathrm{In}_{2} \mathrm{O}_{3}$ cubic crystallites to $\mathrm{H}_{2}$ were systematically investigated. A sensing mechanism is also discussed based on experimental findings.

\section{Experimental}

\subsection{Materials}

All of the chemicals were of analytical gradeand were used as-received without any further purification. The indium chloride tetrahyd rate $\left(\mathrm{InCl}_{3}, 4 \mathrm{H}_{2} \mathrm{O}\right)$ and liquid ammonia $\left(\mathrm{NH}_{3}\right)$ solution $(30 \%)$ were purchased from John Baker IncColorado, U.S.A. and Qualigens Fine Chemicals, India, respectively.

\subsection{Synthesis of the $\operatorname{In}_{2} \mathrm{O}_{3}$ nanocubes}

In a typicalsynthesis of $\mathrm{In}_{2} \mathrm{O}_{3}$ nanocubes, $0.29 \mathrm{~g}$ of $\mathrm{InCl}_{3}$ , $4 \mathrm{H}_{2} \mathrm{O}$ was dissolved to double distilled water $(10 \mathrm{~mL})$ to form a solution $\mathrm{A}$. The liquid $\mathrm{NH}_{3}(5 \mathrm{~mL})$ was added to double distilled water $(5 \mathrm{~mL})$ to form a solution $\mathrm{B}$. The solutions A and B were slowly added drop-wise into double distilled water $(50 \mathrm{~mL})$ at room temperature under continuous stirring to form a white precipitate. The resulting white-colored precipitate was harvested by centrifugation, washed several times using double-distilled water and ethanol, and then dried in an oven at $80{ }^{\circ}$ Cover night to obtain the precursor $\operatorname{In}(\mathrm{OH})_{3}$. This precursor was further calcined in air at $300{ }^{\circ} \mathrm{C}$ for $2 \mathrm{~h}$ to obtain the $\mathrm{In}_{2} \mathrm{O}_{3}$ nanocubes. The color of the the precursor was changed from white to pale-yellow during calcination.

\subsection{Characterization}

X-ray diffraction (XRD) analysis was performed with a Bruker diffractometer (D8, Advance, Bruker AXS model) with $\mathrm{CuK}_{\alpha}$ radiation $(\lambda=1.5406 \AA$ ) operating at $40 \mathrm{kV}$ and 40 $\mathrm{mA}$. The transmission electron microscopy (TEM)images were recorded with a transmission electron microscope (HRTEM, Tecnai $G^{2} 20$ Twin, FEI, USA)operating at an accelerating voltage of $200 \mathrm{kV}$. The FTIR spectroscopy analysis was carried out using FTIR spectrometer (FTIR4800, Shimadzu, Japan) by the conventional $\mathrm{KBr}$ method in the spectral range $4000-400 \mathrm{~cm}^{-1}$.

\subsection{Gas Sensing Measurements}

$\mathrm{TheIn}_{2} \mathrm{O}_{3}$ powder was pressed into pellets under a pressure of $15 \mathrm{MPa}$ and the ohmic contacts were made with the help of silver paste to form the sensing element. The gas sensing measurements were carried out on these sensing elements in a static gas chamber to sense hydrogen in air ambient. The sensing element was kept directly on a heater in the gas chamber and the temperature was varied from 50 to $400{ }^{\circ} \mathrm{C}$. The temperature of the sensing element was monitored by chromel-alumel thermocouple placed in contact with the sensor. The known volume of the $\mathrm{H}_{2}$ was introduced into the gas chamber pre-filled with air and it was maintained at atmospheric pressure. The electrical resistance of the sensing element was measured before and after exposure to hydrogen using a sensitive digital multimeter (2000, Digital Multimeter, Keithley, U.S.A)controlled by a personal computer. The performance of the sensing element is presented in terms of gas response (S), which is defined as :

$$
\mathrm{S}=\frac{\mathbf{R}_{\text {air }}}{\mathbf{R}_{\text {gas }}}
$$

where $R_{\text {air }}$ and $R_{\text {gas }}$ are the electrical resistance values of the sensor element in air and in the presence of $\mathrm{H}_{2}$ gas, respectively.

\section{Results and Discussion}

\subsection{Structural and morphological characteristics}

The XRD pattern of the calcinied product is shown in Fig.1(a). It exhibits the diffraction peaks at $2 \theta$ values of $29.78^{\circ}, 31.16^{\circ}, 34.52^{\circ}, 44.99^{\circ}, 50.24^{\circ}, 57.11^{\circ}$ and $59.63^{\circ}$, which are attributed to the formation of cubic phase of $\mathrm{In}_{2} \mathrm{O}_{3}$ (JCPDS No. 01-073-6440). No other peaks were observed, indicating that no impurities were present and confirming that the adopted synthesis method gives pure $\mathrm{In}_{2} \mathrm{O}_{3}$.

The FTIR spectrum of the calcinied product is shown in Fig.1(b).It shows the bands at approximately 424, 561 and $603 \mathrm{~cm}^{-1}$ (inset of Fig.1(b)) corresponding to the cubic $\mathrm{In}_{2} \mathrm{O}_{3}$ phase. The bands at 424 and $561 \mathrm{~cm}^{-1}$ are attributed to InOstretching whereas the band at $603 \mathrm{~cm}^{-1}$ is a characteristic of $\mathrm{In}-\mathrm{O}$ bending vibrations in the cubic $\mathrm{In}_{2} \mathrm{O}_{3}[23,24]$. In addition, the broad band at $\sim 3450 \mathrm{~cm}^{-1}$ may be assigned to the stretching vibrational mode of an $\mathrm{O}-\mathrm{H}$ group bonded to the In atom, i.e., In-OH [24]. Thus, FTIR spectroscopy result reveals that the phase formation is complete for the assynthesized $\mathrm{In}_{2} \mathrm{O}_{3}$ nanocubes and there is no evidence for the presence of any byproduct (s) in the sample.

The surface morphologies of the calcinied product [Fig.1(c)] reveals the formation $\operatorname{In}_{2} \mathrm{O}_{3}$ nanocubes with a typical edge length of $\sim 25 \mathrm{~nm}$. The corresponding selected area electron diffraction (SAED) pattern [Fig.1(d)] further confirms the random orientations of the $\operatorname{In}_{2} \mathrm{O}_{3}$ nanocubes and that no secondary phase exists.

\section{2 $\mathrm{H}_{2}$ sensing Characteristics}

To evaluate the potential applicability of as-prepared $\operatorname{In}_{2} \mathrm{O}_{3}$ nanocubesin gas sensing applications, their $\mathrm{H}_{2}$ sensing properties were investigated. It is well known that for metal oxide gas sensors, the operating temperature is an important factor and the response of the gas sensor exhibits a maximum value at a certain operating temperature. In order to determine the optimum operating temperature for $\mathrm{H}_{2}$ gas detection, the response of as-prepared $\mathrm{In}_{2} \mathrm{O}_{3}$ nanocubes to $50 \mathrm{ppm} \mathrm{H}_{2}$ was initially measured over an operating temperature range of 150-350 ${ }^{\circ} \mathrm{C}$. Before exposing to the $\mathrm{H}_{2}$ gas, the sensing element was allowed to equilibrate inside the gas chamber at 


\section{International Journal of Science and Research (IJSR) \\ ISSN (Online): 2319-7064 \\ Index Copernicus Value (2013): 6.14 | Impact Factor (2014): 5.611}

an operating temperature for $1 \mathrm{~h}$. A number of experiments have been carried out to measure the gas response as a function of the operating temperature. All the time the gas response of the sensor element has approximately constant values, indicating good repeatability of the sensor. The gas response of the as-prepared $\mathrm{In}_{2} \mathrm{O}_{3}$ nanocubes to $50 \mathrm{ppm} \mathrm{H}_{2}$ as a function of operating temperature is shown in Fig.2(a). At low temperatures, the gas response is relatively low (e.g. $\mathrm{S}=$ 1.1 at $150{ }^{\circ} \mathrm{C}$ ), but it increases rapidly with an increase in the operating temperature. The gas response attains a maximum at $\sim 325^{\circ} \mathrm{C}(\mathrm{S} \sim 127)$ and thereafter it decreases with a further increase of the operating temperature. Thus, the optimum operating temperature for the $\mathrm{In}_{2} \mathrm{O}_{3}$ nanocubes to detect $\mathrm{H}_{2}$ was at $325^{\circ} \mathrm{C}$, which is the modest from the viewpoint of semiconducting oxide gas sensors. Hence, $325^{\circ} \mathrm{C}$ is the optimum operating temperature in this work and further gas sensing experiments were performed at this temperature.

The response and recovery times are also important parameters for evaluating the performance of gas sensors. The response time is defined as the time required by the sensor to reach $90 \%$ of the full response, whereas recovery time is the time required to reach the $10 \%$ of the sensor baseline resistance. The response and recovery characteristics of the $\mathrm{In}_{2} \mathrm{O}_{3}$ nanocubes to $50 \mathrm{ppmH}_{2}$ gas at $325^{\circ} \mathrm{C}$ is shown in Fig.2(b). Five samples were tested from each batch and each sample was tested three times. It was observed that the response of the sensor increases when exposed to the $\mathrm{H}_{2}$ (reducing gas) gas, which suggests that $\mathrm{In}_{2} \mathrm{O}_{3}$ nanocubes behaves as a n-type semiconductor. As can be seen from Fig.2(b), the sensor responds rapidly after introduction of $\mathrm{H}_{2}$ gas and recovers immediately when it is exposed to air. The $\mathrm{In}_{2} \mathrm{O}_{3}$ nanocubes has response time of $\sim 1-2 \mathrm{~s}$ and the recovery time of $\sim 4-5 \mathrm{~s}$.

The reproducibility and stability are important parameters to be considered when evaluating the performance of a sensor. It is useful to have both a stable base line resistance and a reproducible signal change to a given analyte concentration. The reproducibility and stability of the $\mathrm{In}_{2} \mathrm{O}_{3}$ nanocubes gas were measured by repeating the test three times. The gas response of the $\mathrm{In}_{2} \mathrm{O}_{3}$ nanocubes upon periodic exposure to $50 \mathrm{ppm} \mathrm{H}_{2}$ gas at $325^{\circ} \mathrm{C}$ is shown in inset of Fig.2(b). The $\mathrm{In}_{2} \mathrm{O}_{3}$ nanocubes show good reproducibility upon repeated exposure and removal of $\mathrm{H}_{2}$ under same conditions. Furthermore, the repeated tests revealed that the gas response values are maintained and the recovery abilities are not reduced after several sensing cycles. Thus, the $\operatorname{In}_{2} \mathrm{O}_{3}$ nanocubes exhibit a stable and reproducible characteristic, which suggests that itcan be used as a reusable sensing material for the detection of $\mathrm{H}_{2}$ gas.

The gas response of the as-prepared $\operatorname{In}_{2} \mathrm{O}_{3}$ nanocubes as a function of $\mathrm{H}_{2}$ gas concentration at an operating temperature of $325^{\circ} \mathrm{C}$ is shown in Fig.2(c). The gas response increases approximately linearly as the $\mathrm{H}_{2}$ concentration increases from 5 to $60 \mathrm{ppm}$. The linear relationship between the gas response and that of the $\mathrm{H}_{2}$ concentration can be expressed as

$$
y=12.99+1.99 x_{x} R=0.9967
$$

where $x, y$ and $\mathrm{R}$ represent the $\mathrm{H}_{2}$ concentration, gas response and correlation coefficient, respectively. The broken lines in the Fig.2(c) indicate the linear fit to the experimental data, illustrating the good quality of the fit. The linearity of the gas response suggests that the $\mathrm{In}_{2} \mathrm{O}_{3}$ nanocubes can be reliably used to monitor the concentration of $\mathrm{H}_{2}$ over this range. Detection limit is another important factor used for the evaluation of the sensing-performance of the sensors. It is defined as the lowest concentration of the analyte at which the response of the sensor under the given conditions is differentiated from the background level. When this criterion is applied in the present work, the $\mathrm{H}_{2}$ response was set to $S>7.71$. According to the equation (2), the detection limit is estimated to be approximately $3.87 \mathrm{ppm}$ for the sensor based on as-prepared $\mathrm{In}_{2} \mathrm{O}_{3}$ nanocubes. The permissible exposure limit (PEL) for $\mathrm{H}_{2}$ as specified by National Institute for Occupational Safety and Health (NIOSH) is $4 \mathrm{ppm}$. In this work, the detection limit for $\operatorname{In}_{2} \mathrm{O}_{3}$ nanocubes is $\sim 3.87 \mathrm{ppm}$ which is lower than the PEL for $\mathrm{H}_{2}$.

Selectivity is an important parameter of gas sensors and it is the ability of a sensor to respond to a certain gas in presence of othergases. Theoretically, the sensors should have high response to some gases and little or no response to other gases in the same surroundings. The $\mathrm{H}_{2}$ sensing selectivity of the $\mathrm{In}_{2} \mathrm{O}_{3}$ nanocubes is examined towards various gases such as liquid petroleum gas (LPG), carbon monoxide (CO), carbon dioxide $\left(\mathrm{CO}_{2}\right)$ and ethanol $\left(\mathrm{C}_{2} \mathrm{H}_{5} \mathrm{OH}\right)$ at $50 \mathrm{ppm}$ and $325^{\circ} \mathrm{C}$. The responses to each gas were calculated by equation (1). Fig. 2(d) depicts the histogram of the responses of the sensor based on $\mathrm{In}_{2} \mathrm{O}_{3}$ nanocubes toward $50 \mathrm{ppm}$ of LPG, $\mathrm{H}_{2}, \mathrm{CO}$, $\mathrm{CO}_{2}$ and ethanol at $325{ }^{\circ} \mathrm{C}$. The $\mathrm{In}_{2} \mathrm{O}_{3}$ nanocubes exhibit higher response to $\mathrm{H}_{2}$ (127), whereas it shows a considerably lower response $(<39.54)$ to $\mathrm{LPG}, \mathrm{CO}, \mathrm{CO}_{2}$ and ethanol. The selectivity coefficient $(\mathrm{K})$ of $\mathrm{H}_{2}$ to another gas is defined as [25]:

$$
\mathbf{K}=\frac{\mathbf{S}_{\mathrm{H} 2}}{\mathbf{S}_{\mathrm{B}}}
$$

where $\mathrm{S}_{\mathrm{H} 2}$ and $S_{\mathrm{B}}$ are the responses of sensors in $\mathrm{H}_{2}$ and $\mathrm{B}$ gas, respectively. The selectivity coefficients for the $\mathrm{In}_{2} \mathrm{O}_{3}$ nanocubes were 99.21 to $\mathrm{CO}_{2}, 93.38$ to $\mathrm{CO}, 40.70$ to $\mathrm{NH}_{3}$, 18.43 to ethanol,6.85 to acetone and3.21 to LPG, Commonly, the selectivity coefficient of sensors should be more than 5 . Thus, the experimental results indicate that the $\mathrm{In}_{2} \mathrm{O}_{3}$ nanocubes based sensor has a good selectivity to $\mathrm{H}_{2}$. Based on the observed results, it can be concluded that the formation of $\mathrm{In}_{2} \mathrm{O}_{3}$ nanocubes is not only effective in enhancing the $\mathrm{H}_{2}$ response but also in making it selective for the detection of $\mathrm{H}_{2}$.

\section{Conclusions}

In summary, we reported a highly selective and fastresponding $\mathrm{H}_{2}$ sensor based on $\mathrm{In}_{2} \mathrm{O}_{3}$ nanocubes synthesized via a wet chemical route at room temperature. The gas sensing measurements reveal that the sensor based on the $\mathrm{In}_{2} \mathrm{O}_{3}$ nanocubes exhibit higher response ( 127 to $50 \mathrm{ppm} \mathrm{H}_{2}$ gas at $\left.325^{\circ} \mathrm{C}\right)$, response time $(\sim 1-2 \mathrm{~s})$, recovery time $(\sim 4-5 \mathrm{~s})$, excellent reproducibility, good sensing selectivity, and lower detection limit $\left(\sim 3.87 \mathrm{ppm} \mathrm{H}_{2}<\mathrm{PEL}\right)$ and relatively lower operating temperature $\left(\sim 325^{\circ} \mathrm{C}\right)$. This work demonstrates the potential of using $\mathrm{In}_{2} \mathrm{O}_{3}$ nanocubes as sensing material in the fabrication of $\mathrm{H}_{2}$ sensors. 


\section{International Journal of Science and Research (IJSR) \\ ISSN (Online): 2319-7064}

Index Copernicus Value (2013): 6.14 | Impact Factor (2014): 5.611

\section{Acknowledgement}

The authors acknowledge financial support from University Grants Commission (UGC), New Delhi (Project No. F. 530/2/DRS/2010 -SAP-DRS, Phase-II). One of us (SST) is thankful to North Maharashtra University, Jalgaon for providing financial support through the VCRMS Scheme.

\section{References}

[1] G. Haoshuang, W. Zhao and H. Yongming, Hydrogen gas sensors based on semi conductoroxide nanostructures, Sensors, 2012, 12, 5517-5550.

[2] S. Verhelst, R. Sierens, Hydrogen engine-specific properties,Int. J. Hydrogen Energy, 2001, 26, 987-990.

[3] T. Hübert, L. Boon-Brett, G. Black and U. Banach, Hydrogen sensors-A review,Sens. Actuat., B 2011, 157, 329-352.

[4] W. J. Buttner, M. B. Post, R. Burgess and C. Rivkin, An overview of hydrogen safety sensors and requirements, Int. J. Hydrog. Energy, 2011, 36, 2462-2470.

[5] V. Aroutiounian, Hydrogen detectors, Int. Sci. J. Altern. Energy Ecol., 2005, 3, 21-31.

[6] Y. Wang, B. Liu, S. Xiao, H. Li, L. Wang, D. Cai, D. Wang, Y. Liu, Q. Li and T. Wang, High performance and negative temperature coefficient of low temperature hydrogen gassensors using palladium decorated tungsten oxide,J. Mater. Chem. A2015, 3, 1317-1324.

[7] N. H. Al-Hardan, M. J. Abdullah,A. A. Aziz, Sensing mechanism of hydrogen gas sensor based on RFsputtered $\mathrm{ZnO}$ thin films, Int. J.Hydrogen Energy, 2010, 35, 4428-4434.

[8] S. Sumida, S. Okazaki, S. Asakura, H. Nakagawa,H. Murayama and T. Hasegawa,Distributed hydrogen determination with fiber-optic sensor,Sens. Actuators B, 2005,108, 508-514.

[9] V. Aroutiounian, Metal oxide hydrogen, oxygen and carbon monoxide sensors for hydrogen setups and cells, Int. J. Hydrogen Energy, 2007,32,1145-1158.

[10]P. Wadkar, D. Bauskar, P. Patil, High performance $\mathrm{H}_{2}$ sensor based onZnSnO 3 cubic crystallites synthesized by a hydrothermal method, Talanta,2013, 105, 327-332.

[11] A. Katoch, K. Jae-Hun,J. K. Yong,W. K. Hyoun and S. K.Sang, Bifunctional sensing mechanism of $\mathrm{SnO}_{2}-\mathrm{ZnO}$ composite nano fibers for drastically enhancing the sensing behavior in $\mathrm{H}_{2}$ gas, ACS Appl. Mater. Interfaces, 2015,7, 11351-11358.

[12]Y. Wang, B. Liu, S. Xiao, H. Li, L. Wang, D. Cai,D. Wang,Y. Liu, Q. Li, T. Wang,High performance and negative temperature coefficient of low temperature hydrogen gassensors using palladium decorated tungsten oxide, J. Mater. Chem. A,2015, 3, 1317-1324.

[13] C. Y. Huang, G. C. Lin, Y. J. Wu, T. Y. Lin, Y. J. Yang and Y. F. Chen, Efficient light harvesting by well- aligned $\mathrm{In}_{2} \mathrm{O}_{3}$ nanopushpins as antireflection layer on $\mathrm{Si}$ solar cells, J. Phys. Chem. C, 2011, 115, 13083-13087.

[14] J. Parrondo, R. Santhanam, F. Mijangos and B. Rambabu, Electrocatalytic performance of $\mathrm{In}_{2} \mathrm{O}_{3-}$ supported $\mathrm{Pt} / \mathrm{C}$ nanoparticles for ethanol electrooxidation in direct ethanol fuel cells, Int. J. Electrochem. Sci., 2010, 5,1342-1354.

[15] W. H. Ho, C. F. Li, H. C. Liu, S. K.Yen, Electrochemical performance of $\operatorname{In}_{2} \mathrm{O}_{3}$ thin film electrode in lithium cell, J. Power Sources,2008, 175, 897-902.

[16]D. Zhang, Z. Liu, C. Li,T. Tang,X. Liu, S. Han, B. Lei and $\mathrm{C}$. Zhou, Detection of $\mathrm{NO}_{2}$ down to ppb Levels using Individual and Multiple $\mathrm{In}_{2} \mathrm{O}_{3}$ Nanowire Devices,Nano Lett.,2004, 4, 1919-1923.

[17]P.Nguyen,H.T.Ng,T.Yamada,M. K. Smith, J.Li, J.Han and M.Meyyappan,Direct integration of metal oxide nanowire in vertical field-effect transistor,Nano Lett.,2004, 4, 651-657.

[18] J.Cui, A.Wang, N. L.Edleman, J.Ni, P.Lee, N. R.Armstrong and T. J. Marks, Indium tin oxide alternatives-high work function transparent conducting oxides as anodes for organic light-emitting diodes, $A d v$. Mater.,2001, 13, 1476-1480.

[19]X. J. Huang and Y. K.Choi, Chemical sensors based on nanostructured materials, Sens. Actuators B, 2007, 122 659-671.

[20] A.Qurashi,E. M.Maghraby, T. Yamazaki and T.Kikuta, Catalyst supported growth of $\mathrm{In}_{2} \mathrm{O}_{3}$ nanostructures and their hydrogen gas sensing properties,Sens. Actuators $B, 2010,147,48-54$.

[21]Z. Q.Zheng, L. F.Zhu and B.Wang, $\operatorname{In}_{2} \mathrm{O}_{3}$ Nanotower hydrogen gas sensors based on both schottky junction and thermoelectronic emission,Nano. Res. Letts.,2015, 10, 293-307.

[22] A.Shanmugasundaram, B.Ramireddy,P.Basak,S V.Manorama and S.Srinath, Hierarchical $\operatorname{In}(\mathrm{OH})_{3}$ as a precursor to mesoporous $\operatorname{In}_{2} \mathrm{O}_{3}$ nanocubes: $\mathrm{A}$ facile synthesis route, mechanism of self-assembly and enhanced sensing response toward hydrogen.,J. Phys. Chem. C,2014, 118, 6909-6921.

[23]E. C. C.Souza, J. F. Q. Rey and E. N. S. Muccillo, Synthesis and characterization of spherical and narrow size distribution indium oxide nanoparticles, Appl. Surf. Sci.,2009, 255, 3779-3783.

[24] A.Ayeshamariam, M.Bououdina and C. Sanjeeviraja, Optical, electrical and sensing properties of $\mathrm{In}_{2} \mathrm{O}_{3}$ nanoparticles.,Mater. Sci. Semiconductor Processing, 2013, 16, 686-695.

[25]M. Siemons and U. Simon, Gas sensing properties of volume-doped $\mathrm{CoTiO}_{3}$ synthesized via polyol method, Sens. Actuators B : Chemical, 2007, 126 595-603. 
International Journal of Science and Research (IJSR)

ISSN (Online): 2319-7064

Index Copernicus Value (2013): 6.14 | Impact Factor (2014): 5.611
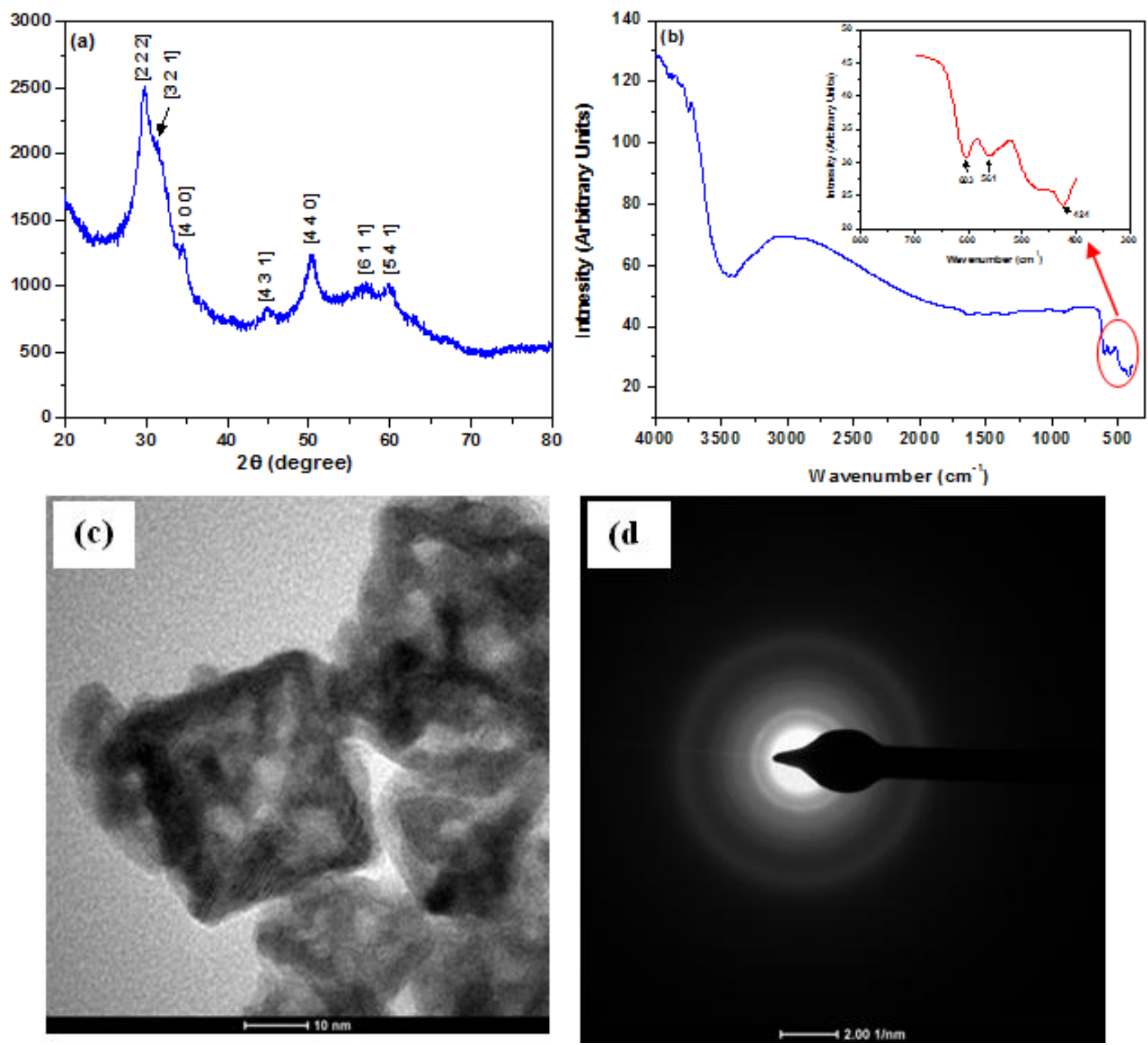

Figure 1: (a) XRD pattern, (b) FTIR spectrum, (c) TEM image and (d) the corresponding SAED pattern of as-synthesized $\mathrm{In}_{2} \mathrm{O}_{3}$ nanocubes.
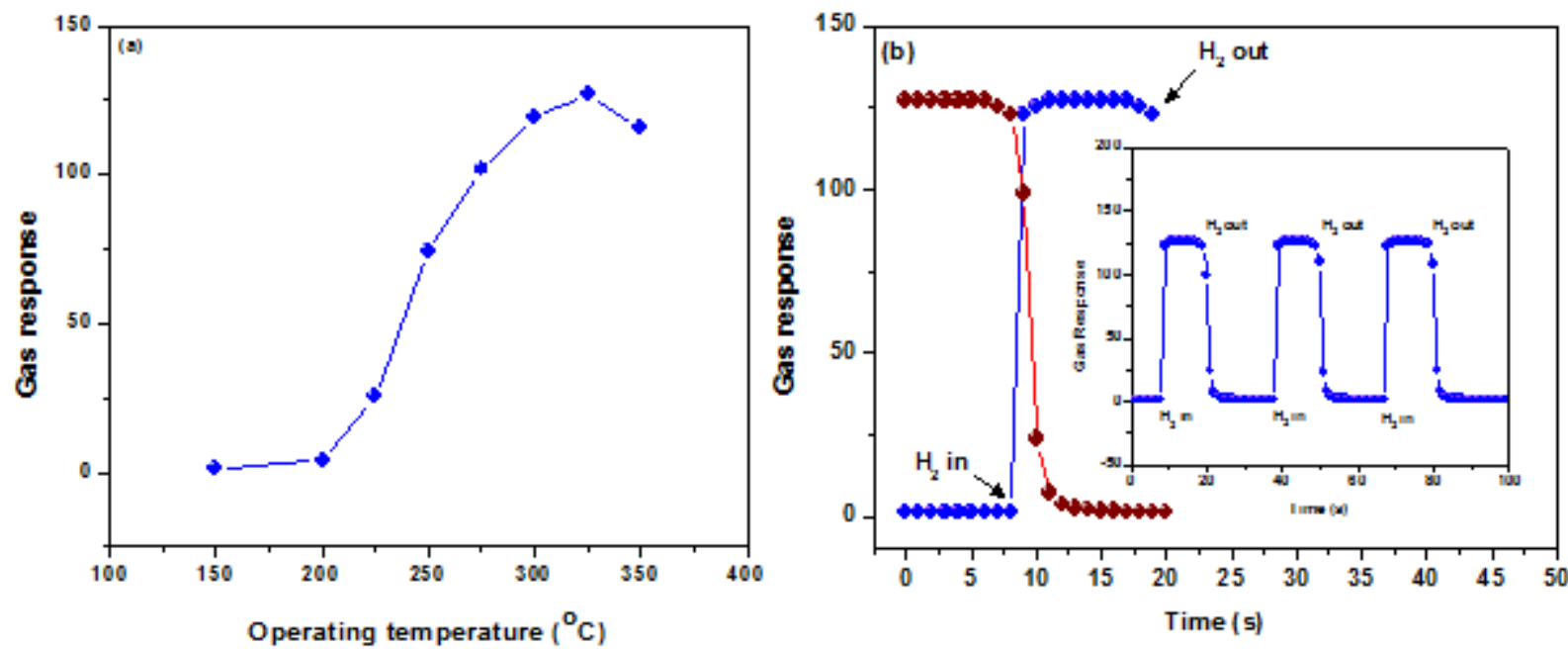

Volume 5 Issue 1, January 2016

www.ijsr.net 

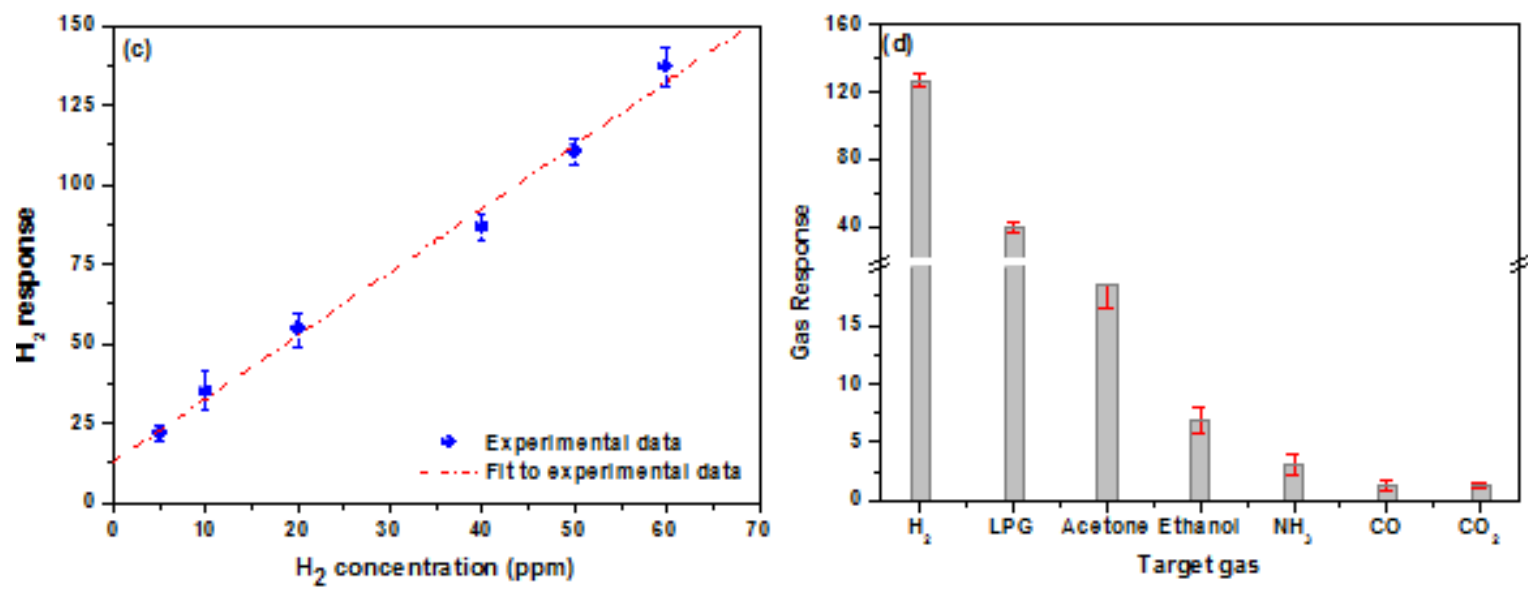

Figure 2: (a) Effect of operating temperature on the gas response of $\operatorname{In}_{2} \mathrm{O}_{3}$ nanocubes to $50 \mathrm{ppm} \mathrm{H}_{2}$ gas, (b) Response and recovery characteristics of $\operatorname{In}_{2} \mathrm{O}_{3}$ nanocubes to $50 \mathrm{ppm} \mathrm{H}_{2}$ gas at $325^{\circ} \mathrm{C}$ (Inset depicts the repetitive response to 50 ppm $\mathrm{H}_{2}$ gas at $325^{\circ} \mathrm{C}$ ), (c) Gas response of $\operatorname{In}_{2} \mathrm{O}_{3}$ nanocubesas a function of $\mathrm{H}_{2}$ concentration at $325^{\circ} \mathrm{C}$ and (d) Bar chart showing the gas response of $\operatorname{In}_{2} \mathrm{O}_{3}$ nanocubes for different gases. The gas concentration and operating temperature in all cases were 50 ppm and $325^{\circ} \mathrm{C}$, respectively. 